\section{Comparison of Stem Diameter Variations in Three Small Ornamental Shrubs under Water Stress}

\author{
Julián Miralles-Crespo ${ }^{1}$ \\ Universidad Politécnica de Cartagena, Producción Vegetal, Paseo Alfonso \\ XIII, 48, 30203 Cartagena, Murcia, Spain
}

\author{
María J. Sánchez-Blanco \\ Departamento de Riego CEBAS-CSIC, C/ Campus Universitario, 14, 30100 \\ Murcia, Spain
}

\begin{abstract}
Alejandra Navarro G.
Unidad Asociada de Horticultura Sostenible en Zonas Áridas CEBAS-CSIC, Departamento de Riego, C/ Campus Universitario, 14, 30100 Murcia, Spain
\end{abstract}

\section{Juan J. Martínez-Sánchez}

Universidad Politécnica de Cartagena, Escuela Técnica Superior de Ingeniería Agronómica, Departamento de Producción Vegetal, Paseo Alfonso XIII, 48, 30203 Cartagena, Murcia, Spain

Jose A. Franco L.

Universidad Politécnica de Cartagena, Escuela Técnica Superior de Ingeniería Agronómica, Departamento de Producción Vegetal, Paseo Alfonso XIII, 48, 30203 Cartagena, Murcia, Spain

\section{Sebastián Bañón A.}

Universidad Politécnica de Cartagena, Escuela Técnica Superior de Ingeniería Agronómica, Departamento de Producción Vegetal, Paseo Alfonso XIII, 48, 30203 Cartagena, Murcia, Spain

Additional index words. pot plant, maximum daily shrinkage, minimum daily stem diameter, maximum stem daily diameter, stem growth rate, evapotranspiration

\begin{abstract}
The dendrometer has been proposed as a sensitive plant water indicator based on stem growth. However, studies including dendrometers have been mainly focused on fruit trees and less attention has been paid to ornamental shrubs (small plants). In the study described here, stem dendrometers were used to ascertain whether there is any relationship between water status and dendrometric indices in potted ornamental shrubs $(1$ to $2 \mathrm{~cm}$ diameter). For this purpose, three Mediterranean shrubs (Pittosporum tobira, Callistemon citrinus, and Rhamnus alaternus) were studied under water stress recovery conditions in winter, spring, and early summer. At the end of the experiment, an extreme water stress treatment, which resulted in plant death (August) was also studied. Stem diameter variations [maximum and minimum daily stem values (MXDS and MNDS, respectively), maximum daily shrinkage (MDS), and stem growth rate (SGR)], daily evapotranspiration (daily plant ET), and leaf water potential ( $\left.\Psi_{\text {leaf }}\right)$ parameters were considered throughout the experiment. A regression analysis between dendrometric indices and daily plant ET showed that MXDS and MNDS were sensitive under water stress recovery conditions, especially in severe environmental conditions (spring and summer). The SGR in $C$. citrinus, the MDS in $P$. tobira, and both indices in $R$. alaternus were seen to be sensitive during the stress to death period. Although more studies are needed, the results confirm that the use of dendrometers in small plants may be useful to provide continuous and automated registers of the plant water status under different substrate water content and climatic conditions. However, the response of these indices may imply moderate water stress.
\end{abstract}

\footnotetext{
Received for publication 27 Apr. 2010. Accepted for publication 8 Aug. 2010.

This work was supported by projects CICYT (AGL 2005-05588-C02-1-2) and Fundación Séneca Región de Murcia (02991/PI/05 and 05660/PI/07). We thank Raquel Valdes for irrigating and supervising the shrubs while the experiment took place. ${ }^{1}$ To whom reprint requests should be addressed; e-mail julian.miralles@upct.es.
}

Irrigation water is in increasingly short supply, which is a grave problem for the nursery sector. There is clear awareness in this sector that high-quality production levels need to be maintained while improving water use efficiency. To attain this, the selection of appropriate species and efficient irrigation scheduling are the nurseryman's best tools. It is therefore necessary to know the water status of a given species so that irrigation scheduling can be adapted to the real water requirements of species (Nemali and van Iersel, 2006).

In irrigation scheduling, it is very common to use soil water sensors because of their good precision (Burnett and van Iersel, 2008). However, in pot crops, the efficient use of such sensors depends on the physical characteristics of the substrate, minimum soil moisture content, and the control of electrical conductivity (EC) in the substrate solution. In recent years, efforts directed at irrigation scheduling based on plant water status have acquired increasing importance, because, as is well known, a plant is the best indicator of its own water status. Besides, water status indicators based on plant measurements have the advantage of being directly related with crop productivity (Goldhamer and Fereres, 2001; Goldhamer et al., 2003). Several parameters, including leaf and stem water potential, leaf conductance, and photosynthesis, are used as plant water status indicators. However, most of these are only used in research, because they are expensive and difficult to operate in real field conditions. Therefore, studies have suggested that one of the most sensitive water indicators is plant growth and, more specifically, trunk diameter growth. One of the consequences of this has been the proposed use of the dendrometer, an electronic sensor that measures the stem diameter variations (SDV) originated by water changes in the trunk tissues (Molz and Klepper, 1973). The high-frequency measurements obtained with this sensor usually point to an MXDS and an MNDS, the difference between them being the MDS. It has been suggested that the MDS is a key indicator of the plant water status (Cohen et al., 2001; Ortuño et al., 2006), and numerous works have studied the relationship among dendrometric indices, plant water status indicators, especially the $\Psi_{\text {leaf }}$ (Intringliolo and Castel, 2004; Li et al., 1989; Yatapanage and So, 2001), and environmental variables such as vapor pressure deficit (Ortuño et al., 2006). However, other important indicators such as ET have been less studied because of the difficulty involved in its precise determination in soil-cultivated trees (Sivyer et al., 1997). When a plant is cultivated in a pot, plant ET can be measured with accuracy (Argo and Biernbaum, 1994; Navarro et al., 2007), and, in this case, the irrigation volume should at least replace the losses occurring through plant transpiration and substrate evaporation.

The use of dendrometers to ascertain the plant water status has mainly focused on fruit trees, in which they have found practical application in irrigation scheduling (Fereres and Goldhamer, 2003; García-Orellana et al., 2007; Nortes et al., 2005). Fewer studies in this respect have been carried out in ornamental shrubs, especially those of small size and cultivated in pots (nursery crops). It is the result of the original design of the dendrometer, which was from the beginning adapted to large trunk diameters (usual in fruit trees); 
also because of the characteristics of pot cultivation, in which the plant water response may differ from that of the soil, because environmental conditions have a much stronger influence on the pot substrate than on soil, mainly because of temperature changes in the roots (Mathers, 2003; Miralles et al., 2009). In this sense, some authors have suggested that MDS behaves differently in pot-cultivated and soil-cultivated plants under water stress (Gallardo et al., 2006).

In gardening and revegetation in Mediterranean areas of Spain, it is very common to use ornamental plants adapted to the Mediterranean climate, particularly shrubs. Among this group predominate traditional shrubs (autochthonous and allochthonous), widely known and offered in commercial nurseries, second, foreign Mediterranean shrubs, mainly Australian or South African flora, which have been introduced in recent years because of their rapid growth, spectacular flowering and colors, and great variety of forms and volumes; and lastly, native shrubs, which have opened an incipient and promising market in the ornamental sector, reflecting present tendencies regarding biodiversity conservation
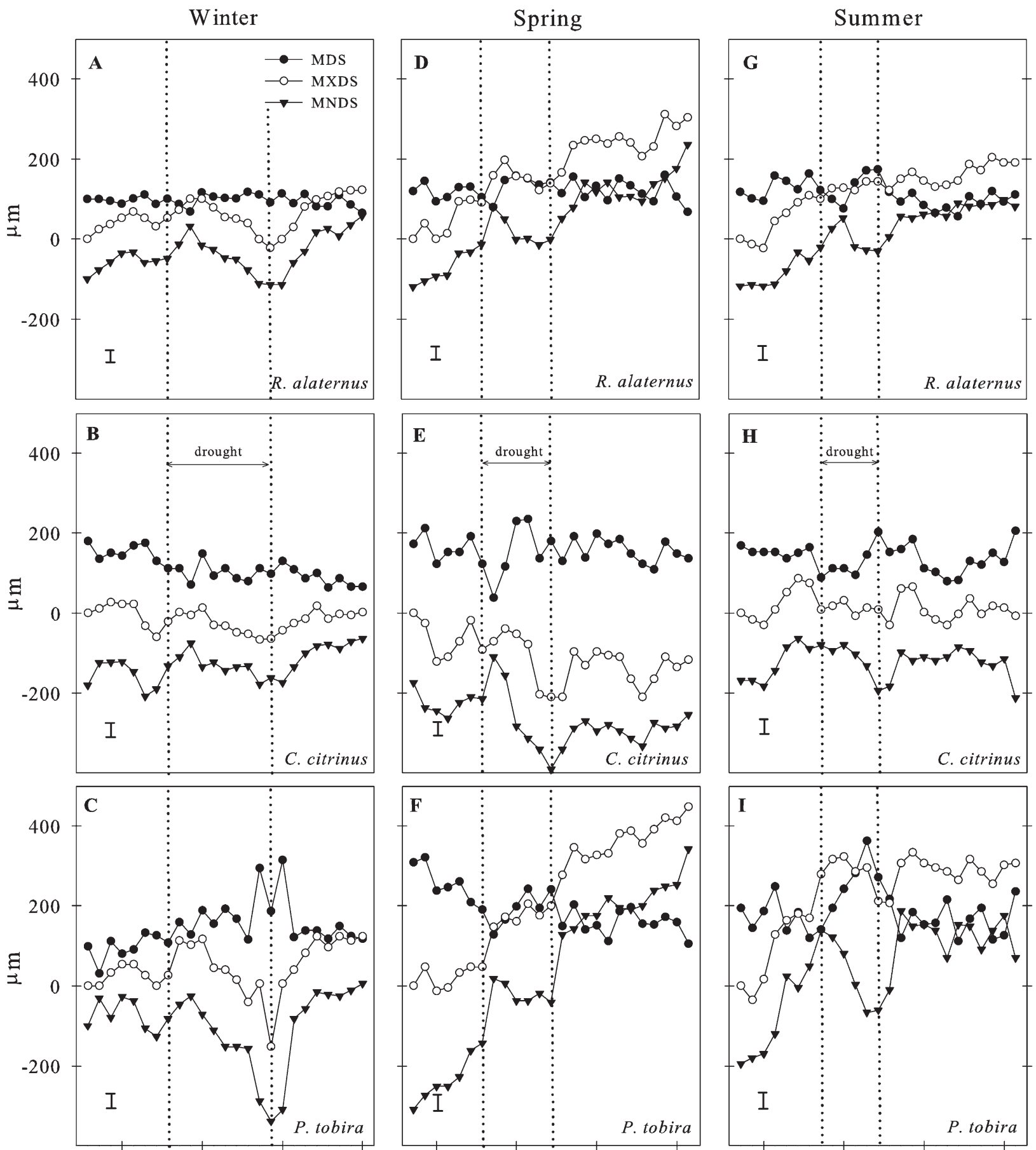

22 Jan. 29 Jan. 5 Feb.12 Feb.

2 May 9 May 16 May 23 May

5 Jun. 12 Jun. 19 Jun. 26 Jun.

\section{DAYS}

Fig. 1. Daily evolution during $25 \mathrm{~d}$ of maximum daily stem value (MXDS), minimum daily stem value (MNDS), and maximum daily shrinkage (MDS) for winter, spring, and summer for drought and recovery period. The drought period is between the two dotted lines (no irrigation in this period). Vertical bars show least significant difference at $P \leq 0.05$. 
and, of course, providing greater adaptability to the environment and stronger resistance to stress. In this work, we study one species of each group: traditional, foreign Mediterranean, and native shrubs.

The objective of this study was to know whether the dendrometic indices could be used as plant water status indicators in wellirrigated and water stress conditions in different ornamental shrubs grown in pots. The response of stem diameter variations and their relationship with the daily ET throughout the growing season were compared in the three species.

\section{Materials and Methods}

Plant material and growing conditions. Three different 1.5- to 2-year-old Mediterranean shrubs of ornamental and landscaping interest were used, one of them native (Rhamnus alaternus L.), one representative of Australian flora [Callistemon citrinus (Curtis). Skeels. cv. Splendens], and the other a very popular commercial shrub from China and Japan [Pittosporum tobira (Thunb.) Ait. cv. Nana]. The first two species have a columnar form, whereas the last one is short and wide.

The plants were transplanted during the first week of Nov. 2007 into black polyvinyl chloride pots that contained a substrate of white peat (40\%), coco fiber $(40 \%)$, and perlite $(20 \%)$ amended with $2 \mathrm{~g} \cdot \mathrm{L}^{-1}$ of a controlledrelease fertilizer (Osmocote plus 10N-4.8P$14.9 \mathrm{~K}-1,2 \mathrm{Mg}+$ microelements; release time 5 to 6 months at $21{ }^{\circ} \mathrm{C}$ ). $R$. alaternus and $C$. citrinus were transplanted to square pots (2.8L volume and $15 \times 15 \mathrm{~cm}$ at the top and $11 \times$ $11 \mathrm{~cm}$ at the base, $20 \mathrm{~cm}$ high). P. tobira was transplanted, first to a circular pot of $14 \mathrm{~cm}$ upper external diameter (1.5 L volume and $12.5 \mathrm{~cm}$ high), and later, in the second week of March, to a circular pot of $16 \mathrm{~cm}$ upper external diameter $(2.5 \mathrm{~L}$ volume and $15 \mathrm{~cm}$ high). The experiment took place in a $100-\mathrm{m}^{2}$ greenhouse with a semicircular cover $(12.5 \mathrm{~m}$ length $\times 8 \mathrm{~m}$ width, $3.5 \mathrm{~m}$ height at the side, and $5.5 \mathrm{~m}$ at the center) covered totally with polycarbonate sheets and located at the Tomás Ferro Experimental Agro-Food Station of the Polytechnic University of Cartagena in " $\mathrm{La}$ Palma" (Cartagena) (lat. 37 $35^{\prime} \mathrm{N}$, long. $0^{\circ} 59^{\prime} \mathrm{W}$ ).

The pots were placed on metal tables $(1.5 \times$ $3 \times 0.9 \mathrm{~m}$ ) provided with a system to collect the water leached per half table. On the tables the plants were set in a $33 \times 33-\mathrm{cm}$ frame so that there were 20 plants per half table. The plants were irrigated at $1000 \mathrm{HR}$ using computer-controlled automated programmable equipment (irrigation head and fertilization Xilema NX300 Hidroponic; Novedades Agrícolas, S.A., Spain) and each pot had one emitter $\left(2 \mathrm{~L} \cdot \mathrm{h}^{-1}\right)$ connected to two spaghetti tubes (one each side of the pot). During the common irrigation period, the doses and frequencies differed for each species. The irrigation volume was determined by noting when the leaching fraction reached $15 \%$ to $20 \%$ and the irrigation frequency by taking into account when pots had lost between
$70 \%$ and $90 \%$ of easily available water in the substrate $(\approx 19 \%$ of pot volume) determined by weight. Irrigation after a drought and recovery period was made until field capacity was reached. One month after transplanting, when plants were established, fertilization was provided at constant concentrations in the irrigation water, which contained $100 \mathrm{~N}-13.1 \mathrm{P}-99.6 \mathrm{~K}-$ $42.9 \mathrm{Ca}(\mathrm{ppm})$ and had a $\mathrm{pH}$ of 6 . This nutrient solution was made by mixing $\mathrm{KNO}_{3}$, $\mathrm{Ca}\left(\mathrm{NO}_{3}\right)_{2}, \mathrm{NH}_{4}\left(\mathrm{NO}_{3}\right), \mathrm{K}\left(\mathrm{HPO}_{4}\right)$, and nitric acid $\left(\mathrm{HNO}_{3}\right)($ Antonio Fuentes Méndez, S.A., Totana, Spain), which was kept in five in- dividual 500-L tanks at a concentration of $6 \mathrm{~kg} \cdot 1000 \mathrm{~L}^{-1}$ for fertilizers and $1 \mathrm{~kg} \cdot 1000 \mathrm{~L}^{-1}$ for nitric acid. The mixture was made up using different injection times that were programmed using the previously mentioned automated programmable equipment. The fertilizers increased the EC of the irrigation water by $\approx 0.7 \mathrm{dS} \cdot \mathrm{m}^{-1}$, which, before fertilization, had an EC of $1.2 \mathrm{dS} \cdot \mathrm{m}^{-1}$ and a $\mathrm{pH}$ of 7.3.

The water stress periods involved withdrawing irrigation in winter (from 26 Jan. to 4 Feb.), spring (from 8 May to 14 May), and early summer (from 11 June to 16 June),
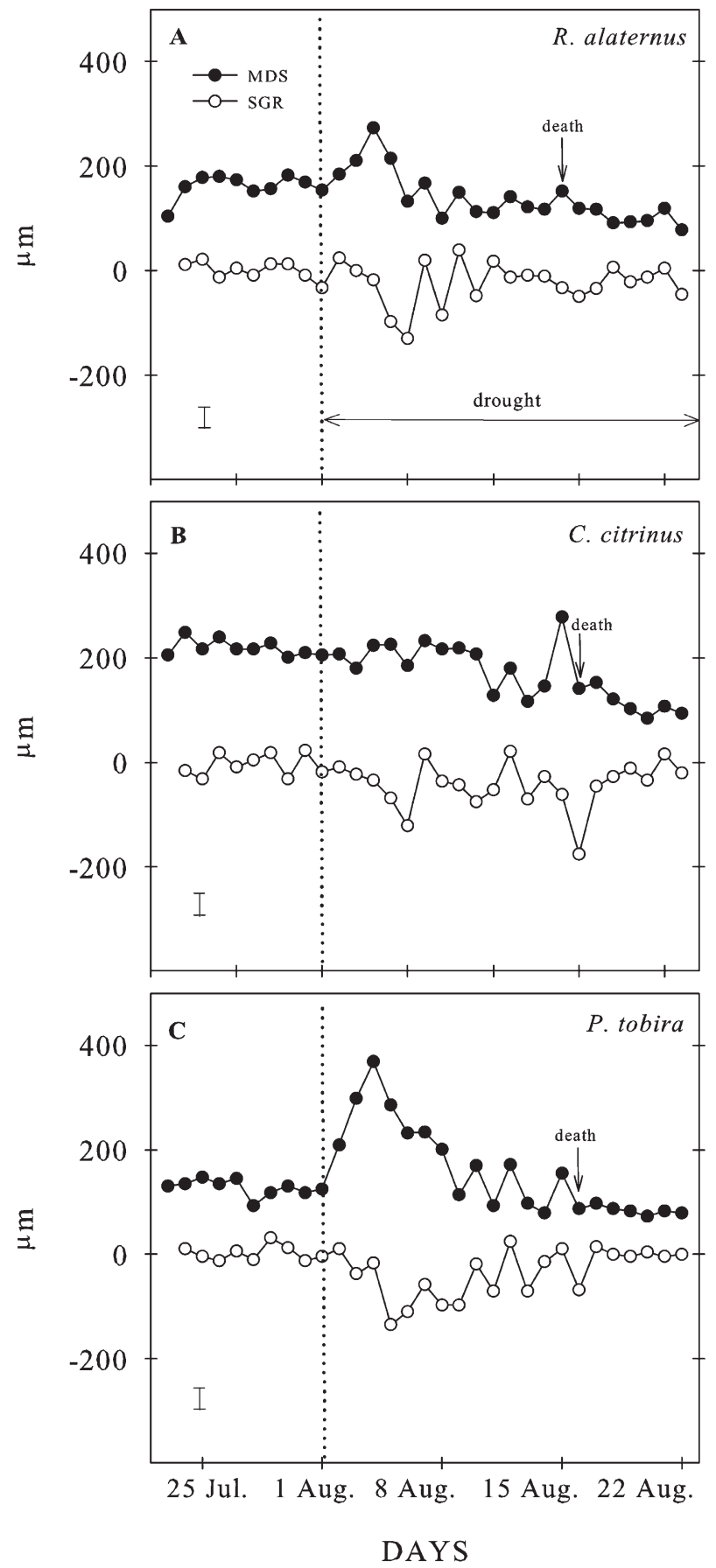

Fig. 2. Daily evolution during $31 \mathrm{~d}$ of stem growth rate (SGR) and maximum daily shrinkage (MDS) for drought to death in summer. Drought period starts at the dotted line (irrigation was stopped at this moment). Arrows shows the day the plants died. The large arrow indicates last irrigation before drought. Vertical bars show least significant difference at $P \leq 0.05$. 
whereas the extreme water stress period was applied from 1 to 31 Aug., which led to plant death.

The temperature and relative humidity were recorded continuously by a data logger (HOBO; H08-004-02; MicroDAQ.com, Ltd.). Calculations of the vapor pressure deficit (VPD) were made using the equation derived by Snyder et al. (1986)

Plant water relations. Midday $\Psi_{\text {leaf }}$ was estimated according to the method described by Scholander et al. (1965), using a pressure chamber (Soil Moisture Equipment Co., Santa Barbara, CA), for which leaves were sealed in the chamber within $20 \mathrm{~s}$ of collection and pressurized at a rate of $0.02 \mathrm{MPa} \cdot \mathrm{s}^{-1}$ (Turner, 1988). Five samples were used for each species, and measurements were taken in drought periods (described in the previous paragraph). The measurements were taken if possible everyday except in summer because of a problem with the pressure chamber. So, in the summer drought and recovery period only the first day and the last day of drought before and after irrigation were registered. In the summer drought to death, measurements were made every $2 \mathrm{~d}$. This methodology was not appropriate for $P$. tobira because it presented a $\Psi_{\text {leaf }}$ that was difficult to explain with very high values during the whole period despite symptoms of withering. In this sense and, like in other species, the determination of the end point is complicated by resin exudation from the pith and cortex or ducts in the xylem (Ritchie and Hinckley, 1975).

The bulk modulus of elasticity $(\varepsilon)$ was estimated by pressure-volume curves as outlined by Wilson et al. (1979) using the formula: $\varepsilon=\left(\mathrm{RWC}_{\mathrm{tlp}} \times \Psi_{\mathrm{os}}\right) /\left(100-\mathrm{RWC}_{\mathrm{tlp}}\right)$, where $\epsilon$ is expressed in $\mathrm{MPa}, \Psi_{\mathrm{os}}$ is the $\psi_{\mathrm{S}}$ at full turgor $(\mathrm{MPa})$, and $\mathrm{RWC}_{\text {tlp }}$ is the relative water content at the turgor loss point. Pressure-volume curves were obtained before the application of water stress in the first week of June in three leaves per plant and five plants per species.

The leaf dehydration kinetic was studied for each species using the same balanceprogrammer system described previously.
To study each species, three balances (Analytical Sartorius, Model 5201; capacity of $5.2 \mathrm{~kg}$ and readability of $0.01 \mathrm{~g}$ ) inside the greenhouse were used in the first week of June. For each species, 12 leaves per plant were taken from the central part of each plant, avoiding young and old leaves. The leaf petioles were immersed in distilled water for $2 \mathrm{~d}$ (in plastic bottles sealed with parafilm) and kept in darkness at 5 to $6{ }^{\circ} \mathrm{C}$. The saturated leaves were then dried with absorbent paper and placed on the balances, where their weight was registered every $5 \mathrm{~min}$. The leaves remained on the balances until the weight was constant, which occurred in less than $48 \mathrm{~h}$ in all cases. After that, the leaves where introduced in an oven at $60{ }^{\circ} \mathrm{C}$ until they reached constant weight, thus providing the dry weight.

Determination of stem diameter variations. In the second week of Dec. 2007, the dendrometers were installed on the stems of the three species to determine the SDVs. The dendrometers (Ecomatic DD, Munich, Germany) were installed $4 \mathrm{~cm}$ from the substrate
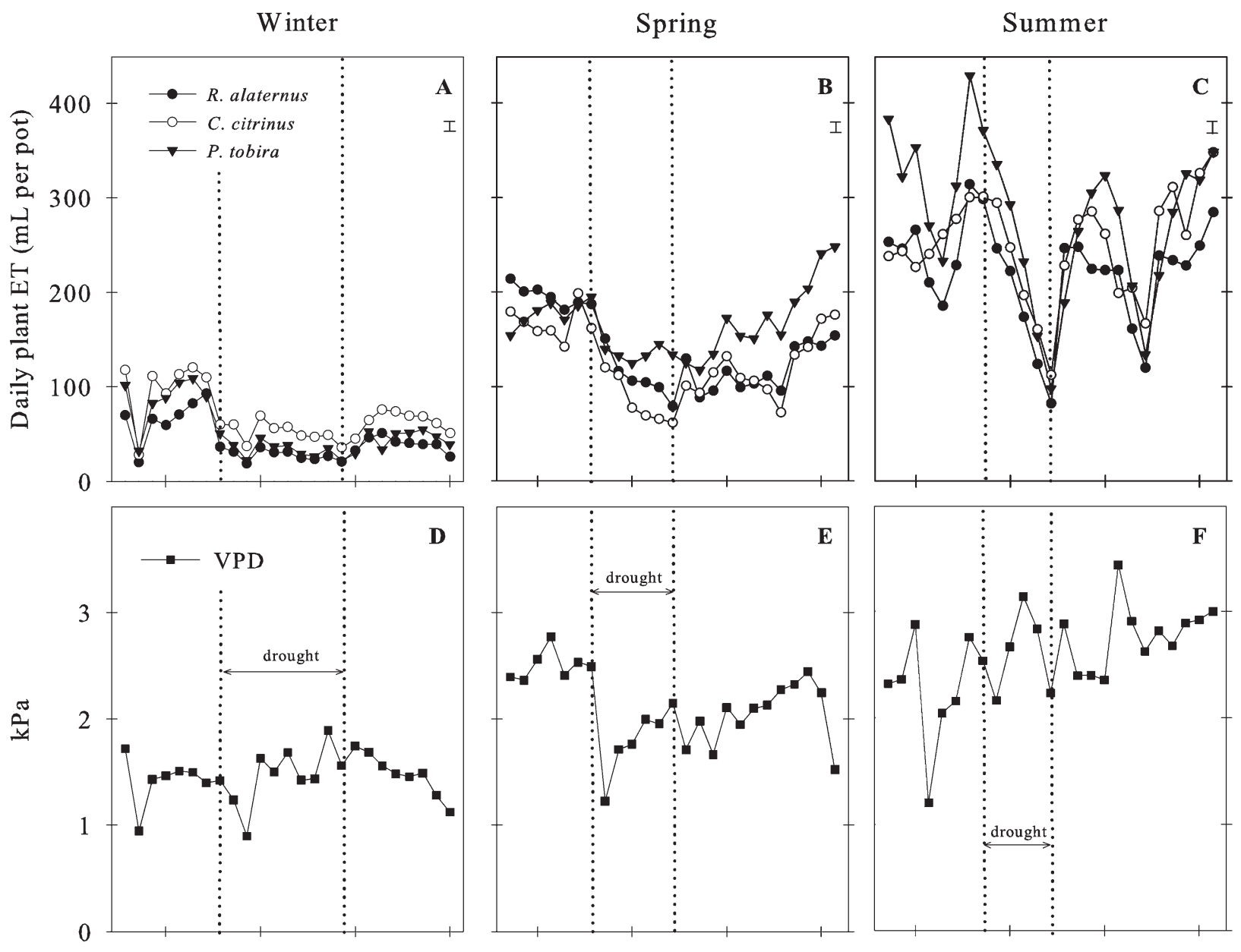

22 Jan. 29 Jan. 5 Feb.12 Feb. 2 May 9 May 16 May 23 May

5 Jun. 12 Jun. 19 Jun. 26 Jun.

\section{DAYS}

Fig. 3. (A-C) Daily plant evapotranspiration (ET) evolution during $25 \mathrm{~d}$ of $R$. alaternus, C. citrinus, and $P$. tobira for winter, spring, and summer with drought and recovery period. Drought period is between the two dotted lines (no irrigation in this period). Vertical bars show least significant difference at $P \leq 0.05$. (D-F) Average daily vapor pressure deficit (VPD) values during the same period. 
on the main stem of each plant (four per species) facing northwest. The measurements were registered every 30 min by a data logger (Ulogger Ecomatik, Munich, Germany). The SDV had 12-bit resolution and an error of 7 $\mu \mathrm{m}$. The MDS was calculated from the SDV as the difference in diameter between the MXDS and the MNDS reached sometime during the afternoon. The SGR was calculated as the difference between two consecutive maximum daily trunk diameters (Ortuño et al., 2010). To facilitate the comparison of the MXDS and MNDS data among species, the maximum values were set at zero so that any losses were registered as negative values.

The SDV measurements were registered from 1 Jan. to 1 Sept., during which time three drought periods were scheduled (winter, spring, and early summer) followed by a fourth one during which the plants died (August). To confirm plant death, it was irrigated for 2 weeks and when it was seen that the leaves remained dry and produced no new shoots, it was considered dead.

Evapotranspiration determination. The plant ET was measured gravimetrically by balances (Analytical Sartorius; Model 5201; capacity of $5.2 \mathrm{~kg}$ and readability of $0.01 \mathrm{~g}$ ) with a MITRA programmer that recorded the weight and temperature every hour. Balances (three for each species) were installed at the same time as the dendrometers. On each balance, a polyvinyl chloride tray slightly inclined to one side and with drainage holes was placed so that the leaching could be collected. This tray also protected balances from water damage and prevented extra weight from being recorded through water leaching.

Treatments, design, and statistical analysis. The plant ET and SDV of the three species were studied during irrigation and water stress periods with a randomized complete block design. There were four blocks of 20 plants per species, which were set on half of a cultivation table. The data were analyzed using a simple analysis of variance with a $P \leq 0.05$. Where appropriate, the least statistical difference $(P \leq 0.05)$ was calculated to indicate differences between treatments. Regression analyses were also determined between SDV indices and daily plant ET and $\Psi_{\text {leaf. }}$ The statistical analysis was performed using Statgraphics Plus 5.1 software and the regression analysis was performed using SigmaPlot 10.0 software.

\section{Results}

Study of the indices derived by the stem diameter variations. To interpret the SDV data, the MNDS, MXDS, and MDS were studied for each species and representative 25-d period (Fig. 1). In winter, a water stress period of $9 \mathrm{~d}$ was applied. $R$. alaternus showed an increasing diameter growth tendency before the stress period (Fig. 1A), but during the stress, both MNDS and MXDS decreased until they reached their lowest values by the end of the water stress period; however, no changes in MDS were found. Four d after suspending the water stress, the diameter quickly recovered in terms of growth and stabilized. C. citrinus behaved in a very similar way, although the trends were less pronounced (more noise; Fig. 1B). However, $P$. tobira showed a great loss in MNDS by the eighth water stress day, resulting in a high MDS; and after the first day of irrigation, both the MNDS and MXDS recovered, leading to a high value of MDS.

In spring and summer during the 7 and $6 \mathrm{~d}$ of water stress, respectively, only $P$. tobira showed higher MDS in the summer. $R$. alaternus behaved similarly in both seasons (Figs. 1D and G). C. citrinus showed a greater fall in MNDS in spring (Fig. 1E) but a less pronounced decrease in summer (Fig. 1H); the MDS response was smoother. P. tobira again showed the highest MNDS decrease by the end of the water stress period and sharpest recovery after irrigation, except in spring, when the MNDS did not fall significantly, although MDS remained high because the MXDS continued to increase (Figs. 1F and I).

In the severe 31-d water stress period (Fig. 2), the SGR started to register negative values (diameter decreasing) in all the plants until it reached a minimum, after which it tended to increase to zero and stabilize at the end as a result of plant death (after $\approx 14,15$, and $15 \mathrm{~d}$ for $R$. alaternus, $C$. citrinus, and $P$. tobira, respectively). However, C. citrinus showed a more irregular tendency than the other two species (Fig. 2A) and it suffered a sudden decrease in SGR and an increase in MDS after $14 \mathrm{~d}$ of water stress (Fig. 2B). The MDS response for $R$. alaternus and $P$. tobira was at peak during the first days of water stress (just contrary to the SGR). C. citrinus only showed a gradual decrease during the water stress period except for the sudden change described.

Evapotranspiration. Higher plant ET levels are associated with high VPD, long days, and large plants (Montero et al., 2001). In general terms, daily plant ET decreased when water stress was applied and when VPD was greater (Figs. 3 and 4). In winter, the differences between the water stress period and irrigation period were slight and $C$. citrinus showed greater daily plant ET (Fig. 3A). In spring, C. citrinus showed the sharpest fall in daily plant ET, whereas $P$. tobira seemed unaffected by water stress (Fig. 3B). In all three species, the sharpest fall in plant ET as well as the sharpest increase after irrigation was observed in summer, but the

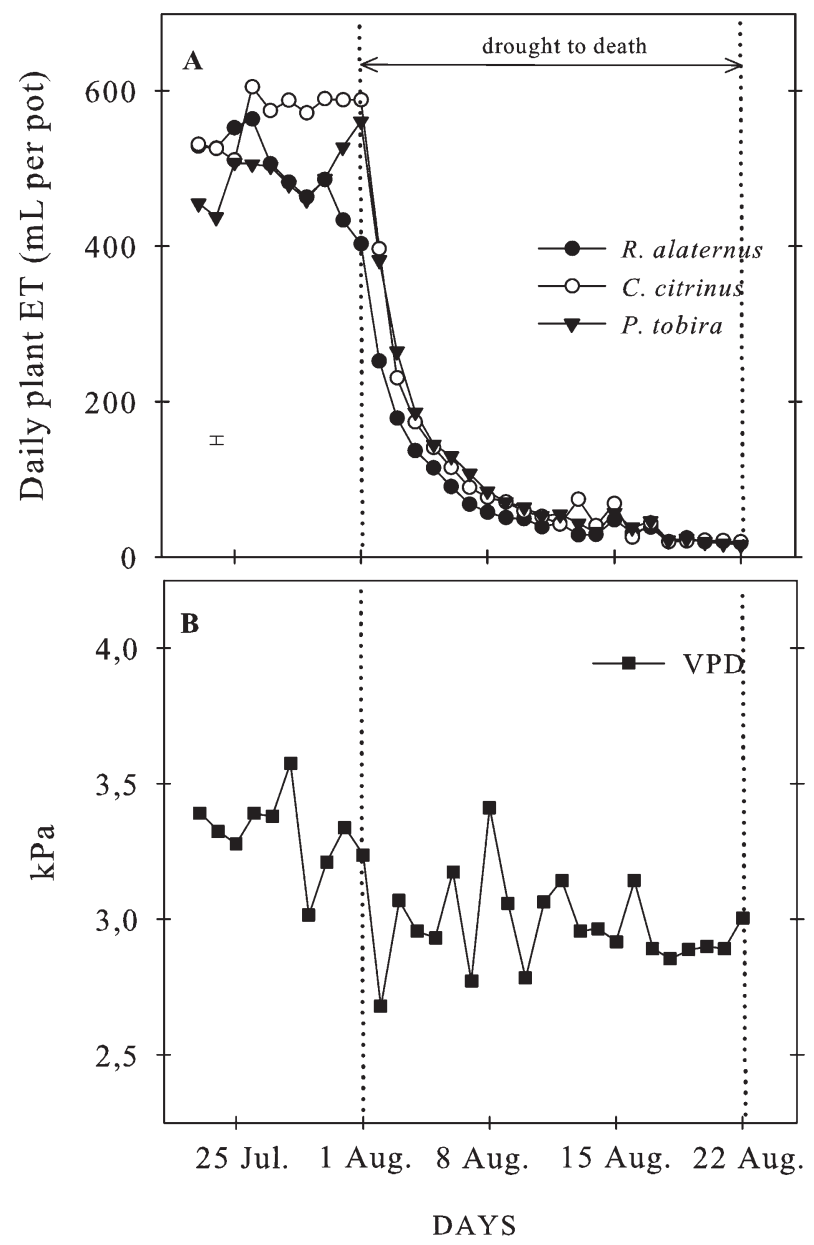

Fig. 4. (A) Daily plant evapotranspiration (ET) evolution during $31 \mathrm{~d}$ of $R$. alaternus, C. citrinus, and $P$. tobira for drought to death in summer. Drought period starts at the dotted line (irrigation was stopped at this moment). Vertical bar show least significant difference at $P \leq 0.05$. (B) Average daily vapor pressure deficit (VPD) values during the same period. 
daily plant ET rate was the lowest in $R$. alaternus (Fig. 3C). In severe water stress conditions, a strong decrease in daily plant ET was observed, although a constant residual daily plant ET was still evident after the plants of the three species had died.

Plant water relations. In the winter drought recovery period, $\Psi_{\text {leaf }}$ decreased in $R$. alaternus and $C$. citrinus until it reached values of $-2.59 \mathrm{MPa}$ and $-2.67 \mathrm{MPa}$, respectively. After irrigation, $\Psi_{\text {leaf }}$ increased to $-1.56 \mathrm{MPa}$ and $-1.0 \mathrm{MPa}$ for $R$. alaternus and $C$. citrinus, respectively (Fig. 5), values that can be considered reference values for shrubs without water stress (De Herralde et al., 1998; Munné-Bosch et al., 1999).

In the spring and summer drought recovery periods, $\Psi_{\text {leaf }}$ reached more negative values than in winter in both species (Fig. 5B-C). In the drought to death conditions, the $\Psi_{\text {leaf }}$ just before the beginning of the water stress period was $-2.55 \mathrm{MPa}$ and $-1.29 \mathrm{MPa}$ in $R$. alaternus and C. citrinus, respectively (Fig. 5D). As the drought progressed, both species reached very negative values of $\approx-4.00 \mathrm{MPa}$ and remained at this level until the leaves were dry, except in the last register of C. citrinus, when it was higher. Regarding the elasticity bulk modulus ( $\epsilon$, derived from $\mathrm{P}-\mathrm{V}$ curves), $R$. alaternus and $C$. citrinus had high $\epsilon$ values $12.17 \mathrm{MPa}$ and $15.51 \mathrm{MPa}$, respectively.

Regression analysis between daily plant evapotranspiration and stem diameter indices. The regression analyses for the water stress period fitted quadratic curves, except for MDS and $R$. alaternus in spring and for MNDS and $C$. citrinus in summer, which were linear (Table 1). The curves for MXDS and MNDS were directly related to daily plant ET. However, the MDS curves showed two different daily plant ET values for the same MDS value in spring and especially in summer: when the daily plant ET started to decrease as a result of water stress, the MDS first increased and then decreased, showing an inverted parabola. In winter, all the regression analyses were quadratic and in $R$. alaternus only ET-MDS was significant (Table 1). In C. citrinus, MXDS was also significant and showed the highest $R^{2}$ for this period, whereas in $P$. tobira, the regressions had $R^{2}<0.30$ (Table 1). However, although some regressions were significant, the daily plant ET was fairly constant and there was no clear relationship because the curves were nearly parallel to the $\mathrm{X}$ axis.

In spring and especially in summer, all the $R^{2}$ increased. The highest $R^{2}$ for $R$. alaternus in both periods was ET-MXDS and for $C$. citrinus ET-MNDS with $R^{2} \geq 0.90$ (Table 1 ). $P$. tobira showed good correlations for both indices in summer, but for spring, the correlations were very weak at $R^{2}<24$ and showed a constant daily plant ET rate (Table 1).

In the irrigation period, all the regressions became linear (Table 2). In general, they showed a positive relation between daily plant ET and stem indices (the higher the daily plant ET, the more the growth) except in winter for MXDS and MNDS in C. citrinus and $P$.
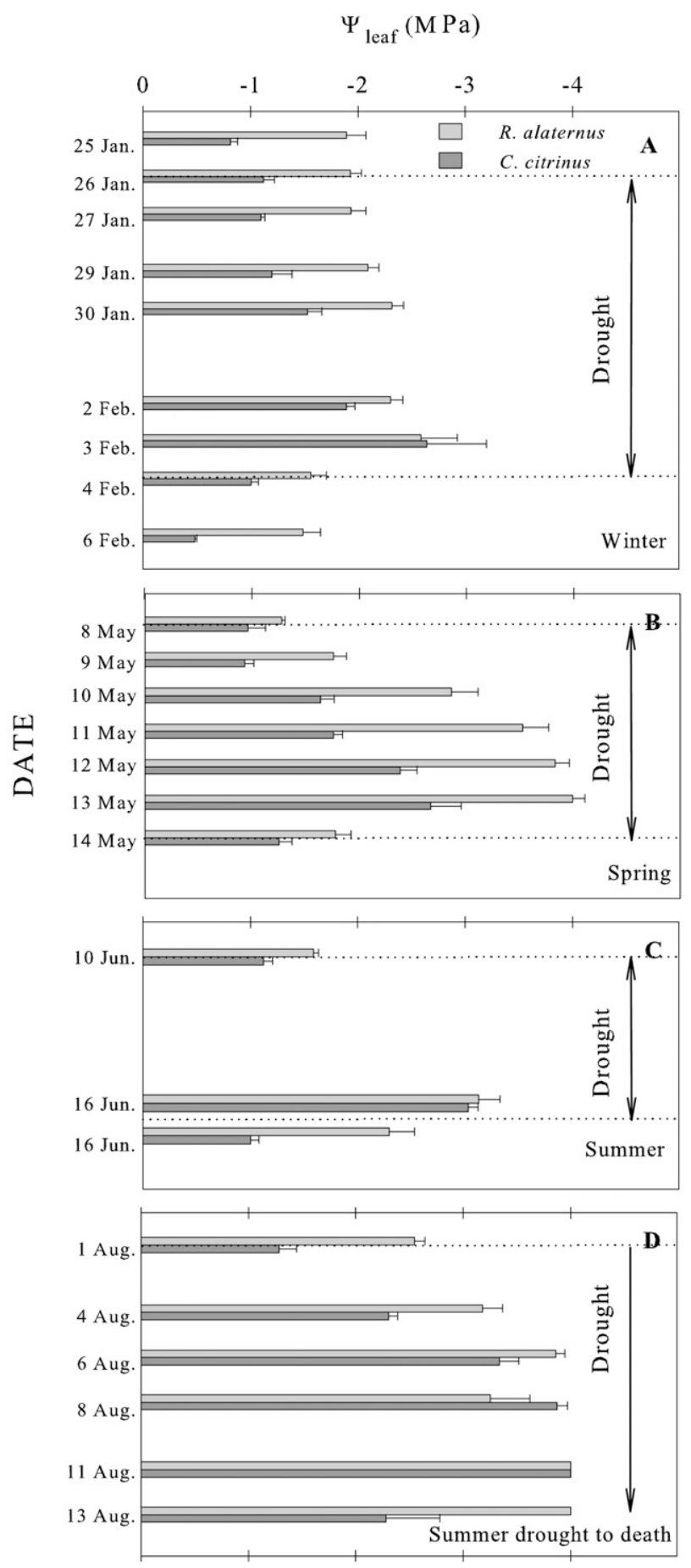

Fig. 5. Leaf water potential evolution for drought and recovery periods winter (A), spring (B), and summer (C) and drought to death period (D). Arrows show irrigation moments. Vertical bars are SE $(n=5)$.

tobira, when they were inversely correlated. The $R^{2}$ were generally $<0.50$, except in summer, when $R$. alaternus and C. citrinus had a greater $R^{2}$ for ET-MXDS (Table 2).

The regressions in the extreme water stress for ET-SGR were inverted peak functions. All the species showed a fairly constant SGR because the SGR inverted peak was produced when plant ET decreased to 100 $130 \mathrm{~mL} \cdot \mathrm{d}^{-1}$ (Fig. 6A). R. alaternus and $P$. tobira had moderate correlations ET-SGR and $C$. citrinus was weak. The ET-MDS regressions were quadratic with $R^{2}>0.70$, except in C. citrinus, which showed the lowest $R^{2}$ (Fig. 6B) and also the most open parabola of the three. So, in $R$. alaternus and $P$. tobira, the MDS tended to increase at the beginning of the water stress, but, when the daily plant ET rate reached $\approx 200 \mathrm{~mL} \cdot \mathrm{d}^{-1}$ in $R$. alaternus and $300 \mathrm{~mL} \cdot \mathrm{d}^{-1}$ in $P$. tobira, the MDS started to decrease (Fig. 6B). However, in $C$. citrinus, because of its open parabola, it was difficult to see any tendency, and the MDS tended to be more or less constant until the daily plant ET had decreased to rates below $100 \mathrm{~mL} \cdot \mathrm{d}^{-1}$. The SGR- $\Psi_{\text {leaf }}$ correlations were 
Table 1. Regression analysis between daily evapotranspiration and stem diameter indices during water stress and recovery periods.

\begin{tabular}{|c|c|c|c|}
\hline & R. alaternus & C. citrinus & P. tobira \\
\hline ET/MXDS & NS & $\begin{array}{c}\text { Winter } \\
\mathrm{y}=0.096 \mathrm{x}^{2}-8.595 \mathrm{x}+189.2 \\
R^{2}=0.50 *\end{array}$ & $\begin{array}{c}\mathrm{y}=-0.232 \mathrm{x}^{2}+20.36 \mathrm{x}-352.7 \\
R^{2}=0.29^{*}\end{array}$ \\
\hline ET/MNDS & NS & NS & $\begin{array}{c}\mathrm{y}=0.106 \mathrm{x}^{2}-3.100 \mathrm{x}-157.1 \\
R^{2}=0.22 *\end{array}$ \\
\hline ET/MDS & $\begin{array}{c}\mathrm{y}=-0.126 \mathrm{x}^{2}+8.331 \mathrm{x}-28.75 \\
R^{2}=0.40^{*}\end{array}$ & $\begin{array}{c}\mathrm{y}=0.045 \mathrm{x}^{2}-3.450 \mathrm{x}+157.8 \\
R^{2}=0.42 *\end{array}$ & $\begin{array}{c}\mathrm{y}=-0.339 \mathrm{x}^{2}+23.46 \mathrm{x}-195.6 \\
R^{2}=0.28^{*}\end{array}$ \\
\hline ET/MXDS & $\begin{array}{c}\mathrm{y}=-0.020 \mathrm{x}^{2}+5.166 \mathrm{x}-138.3 \\
R^{2}=0.65^{*}\end{array}$ & $\begin{array}{c}\text { Spring } \\
\mathrm{y}=-0.040 \mathrm{x}^{2}+9.712 \mathrm{x}-551.3 \\
R^{2}=0.60 *\end{array}$ & $\begin{array}{c}\mathrm{y}=-0.194 \mathrm{x}^{2}+52.19 \mathrm{x}-3393 \\
R^{2}=0.20 *\end{array}$ \\
\hline ET/MNDS & $\begin{array}{c}\mathrm{y}=-0.020 \mathrm{x}^{2}+5.859 \mathrm{x}-346.2 \\
R^{2}=0.48^{*}\end{array}$ & $\begin{array}{c}\mathrm{y}=-0.063 \mathrm{x}^{2}+15.81 \mathrm{x}-1050 \\
R^{2}=0.98 *\end{array}$ & $\begin{array}{c}\mathrm{y}=-0.095 \mathrm{x}^{2}+27.32 \mathrm{x}-2045 \\
R^{2}=0.23 *\end{array}$ \\
\hline ET/MDS & $\begin{array}{r}\mathrm{y}=-0.580 \mathrm{x}+200.9 \\
R^{2}=0.55^{*}\end{array}$ & $\begin{array}{c}\mathrm{y}=0.022 \mathrm{x}^{2}-6.103 \mathrm{x}+498.6 \\
R^{2}=0.48^{*}\end{array}$ & $\begin{array}{c}\mathrm{y}=-0.097 \mathrm{x} 2+24.47 \mathrm{x}-1321 \\
R^{2}=0.11 *\end{array}$ \\
\hline ET/MXDS & $\begin{array}{c}\mathrm{y}=-0.001 \mathrm{x}^{2}+0.503 \mathrm{x}+129.6 \\
R^{2}=0.63 *\end{array}$ & $\begin{array}{c}\text { Summer } \\
\mathrm{y}=-0.001 \mathrm{x}^{2}+0.777 \mathrm{x}-58.27 \\
R^{2}=0.56^{*}\end{array}$ & $\begin{array}{c}\mathrm{y}=-0.002 \mathrm{x}^{2}+1.345 \mathrm{x}-5.847 \\
R^{2}=0.85^{*}\end{array}$ \\
\hline ET/MNDS & NS & $\begin{array}{c}\mathrm{y}=0.599 \mathrm{x}-227.2 \\
R^{2}=0.90 *\end{array}$ & $\begin{array}{c}\mathrm{y}=0.003 \mathrm{x}^{2}-1.000 \mathrm{x}-46.56 \\
R^{2}=0.87 *\end{array}$ \\
\hline ET/MDS & $\begin{array}{c}\mathrm{y}=-0.001 \mathrm{x}^{2}+0.486 \mathrm{x}+112.6 \\
R^{2}=0.30 *\end{array}$ & $\begin{array}{c}\mathrm{y}=-0.001 \mathrm{x}^{2}+0.219 \mathrm{x}+165.1 \\
R^{2}=0.63 *\end{array}$ & $\begin{array}{c}\mathrm{y}=-0.005 \mathrm{x}^{2}+2.346 \mathrm{x}+40.71 \\
R^{2}=0.87^{*}\end{array}$ \\
\hline
\end{tabular}

The number of data used for each regression were $\mathrm{n}=36$ (winter) $\mathrm{n}=28$ (spring), and $\mathrm{n}=24$ (summer). $*$ Statistically significant at $P \leq 0.05$, NS $=$ non-significant. $\mathrm{ET}=$ evapotranspiration; MXDS = maximum daily stem value; MNDS = minimum daily stem value; MDS = maximum daily shrinkage.

Table 2. Regression analysis between daily evapotranspiration and stem diameter indices during irrigation periods.

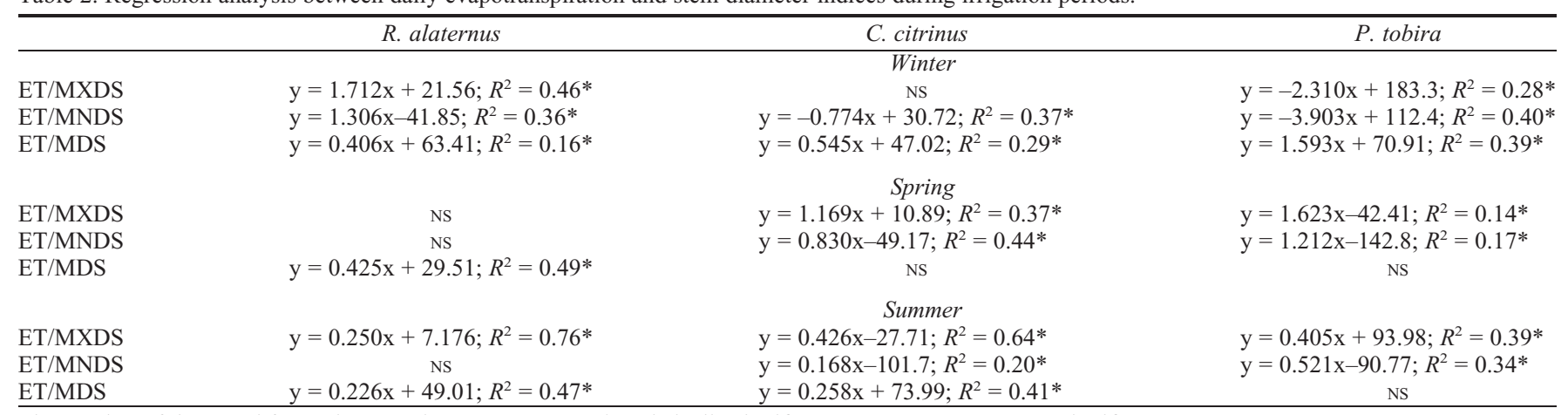

The number of data used for each regression were $\mathrm{n}=124$. ${ }^{*}$ Statistically significant at $P \leq 0.05$, NS $=$ non-significant.

$\mathrm{ET}=$ evapotranspiration; MXDS = maximum daily stem value; MNDS = minimum daily stem value; MDS = maximum daily shrinkage

three-grade polynomial, which mainly described an inverted peak (more closed for $R$. alaternus) whose minimum point was between -4.00 and $-3.00 \mathrm{MPa}$ (Fig. 6C). The MDS- $\Psi_{\text {leaf }}$ was only significant for $R$. alaternus and similar to the ET-MDS correlation but with the highest point at $\approx-3.00 \mathrm{MPa}$ (Fig. 6D).

\section{Discussion}

The stem dendrometer indices showed a response to water stress. This was especially clear in $P$. tobira, which is of great interest because of the difficulty involved in obtaining $\Psi_{\text {leaf }}$, suggesting that this may be an easy way to ascertain the water status of this plant. Previous studies in peach and plum found a more sensitive response of SDV to different irrigation treatments than stem water potential (Intrigliolo and Castel, 2004; Remorini and Massai, 2003). The strongest responses were found for MXDS and MNDS in all the water stress and recovery periods, but especially in high water=demanding conditions (spring and summer). This behavior could be related to the greater tissue water loss by the higher daily plant ET rates (Alarcón et al., 2000; Cohen et al., 1993; Nicolás, 2003). In the drought to death, $C$. citrinus suffered a strong decrease in diameter after $14 \mathrm{~d}$ (Fig. 2B), which could reflect a sudden collapse of stem tissues, leading to plant death resulting from strong leaf dehydration as reflected by the leaf dehydration kinetic (data not shown). This fact can explain the value of $\Psi_{\text {leaf }} 1 \mathrm{~d}$ before the collapse (Fig. 5D) because only a few young leaves remained alive.

In general, MXDS had a similar response to MNDS and the diameter growth decreased under water stress, which was also observed by Wei et al. (2007) in conifers. Nevertheless, in $P$. tobira during the spring water stress period, MXDS continued to increase (Fig. $1 F$ ), whereas MNDS decreased slightly (Fig. 1D-E). The transplantation of P. tobira to a bigger pot in spring would have decreased the plant/substrate ratio, favoring greater water availability and maintaining daily plant ET rates constant (Fig. 3B), and the greater water availability did not permit a significant decrease in MNDS. Gallardo et al. (2006) in pepper also observed the absence of any response of the MDS to drought when the plants were cultivated in the field rather than in pots because of the greater water availability.

MDS increased in fruit trees subjected to moderate water deficit (Huguet et al., 1992). However, in this experiment, this behavior was only clear in P. tobira for spring and summer. On the other hand, in the drought to death period, $R$. alaternus showed an increasing MDS, which, after suffering moderate stress $\left(\Psi_{\text {leaf }}\right.$ less than $\left.-3.00 \mathrm{MPa}\right)$, started to decrease again (Fig. 6D). This change in MDS behavior may be attributed to the end of water recruitment form the bark, including phloem and cambium, when the water stored in the stem is reduced (Garnier and Berger, 1986; Huguet et al., 1992; Remorini and Massai, 2003). After plant death, MDS and daily plant ET were constant, probably as a result of hydration at night resulting from the presence of dew and the dehydration of wood and substrate during the day. Furthermore, the dendrometer could also be affected by temperature (Link et al., 1998), which would contribute to the residual MDS. In winter, none of the studied species showed any MDS 

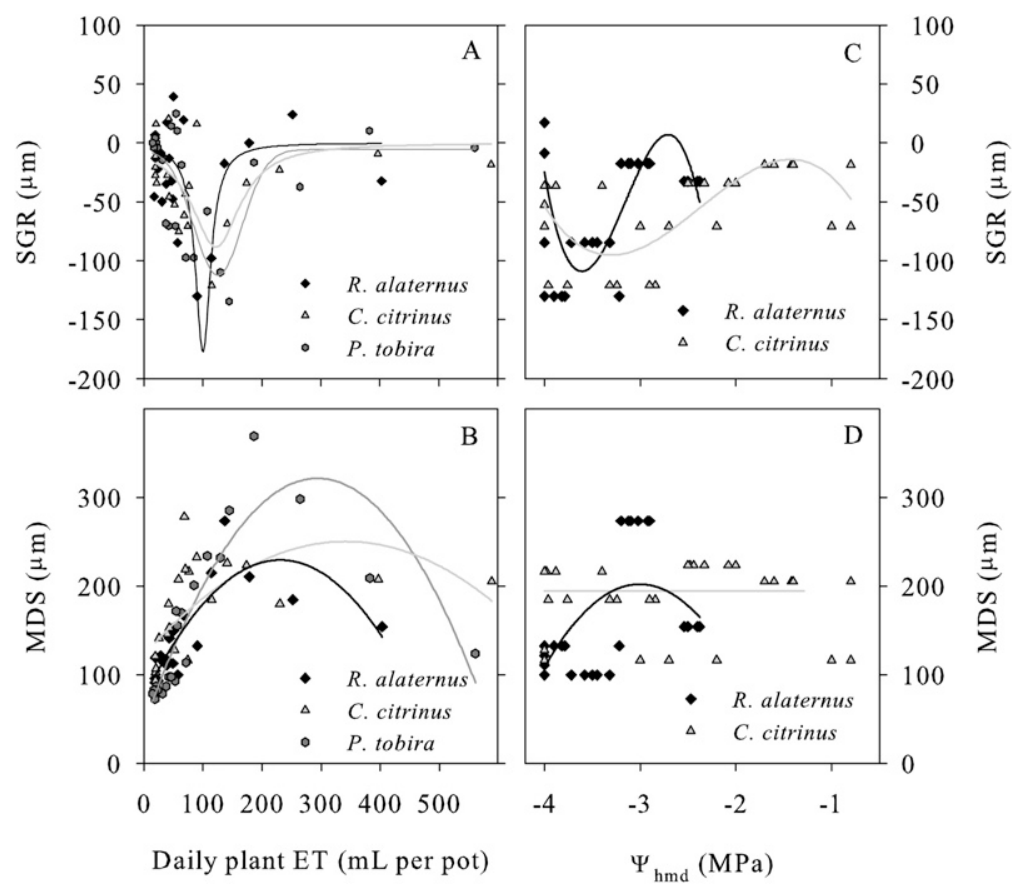

Fig. 6. Analysis of regression between daily evapotranspiration-stem growth rate (ET-SGR) (A), daily ET-maximum daily shrinkage (MDS) (B), water potential $(\Psi)_{\text {hmd }}-$ SGR (C) and $\Psi_{\text {hmd }}-$ MDS (D) during the drought to death period. The regression analysis equations are: ET-SGR $y=-177 /\{[1+(\mathrm{x}-$ $\left.100.1) / 15.65]^{2}\right\}, R^{2}=0.48 *$ for $R$. alaternus, $\mathrm{y}=-88.32 /\left\{1+[(\mathrm{x}-122.07) / 50.20]^{2}\right\}, R^{2}=0.33 *$ for $C$. citrinus, and $\mathrm{y}=-5.661+-106.6^{*} \mathrm{e}^{\wedge}-0.5^{*}\left\{[(\mathrm{x}-125,5) / 41,03]^{2}\right\}, R^{2}=0.52^{*}$ for P. tobira. ET-MDS $\mathrm{y}=-0.002 \mathrm{x}^{2}+1.343 \mathrm{x}+74.47, R^{2}=0.71 *$ for $R$. alaternus, $\mathrm{y}=-0.001 \mathrm{x}^{2}+0.748 \mathrm{x}+122.4, R^{2}=0.37^{*}$ for $C$. citrinus, and y $=-0.003 \mathrm{x}^{2}+1.899 \mathrm{x}+42.49, R^{2}=0.83 *$ for $P$. tobira. $\Psi_{\mathrm{hmd}}-\mathrm{SGR} \mathrm{y}=-9426.3-$ $9292.03 \mathrm{x}-3002.1 \mathrm{x}^{2}-316.8 \mathrm{x}^{3}, R^{2}=0.37$ for $R$. alaternus, $\mathrm{y}=-227,09-348.21 \mathrm{x}-174,47 \mathrm{x}^{2}-24,6 \mathrm{x}^{3}, R^{2}=$ 0,42 for C. citrinus. $\Psi_{\mathrm{hmd}}-\mathrm{SGR}$ y $=-654.06-569.76 \mathrm{x}-94.76 \mathrm{x}^{2}, R^{2}=0.42$ for $R$. alaternus, not significant in C. citrinus. *Statistically significant at $P \leq 0.05$.

response and C. citrinus did not show any MDS response in any period. Perhaps, the low vegetative activity and VPD in winter were not sufficient to produce an MDS response (Ginestar and Castel, 1996; Huguet et al., 1992). The lack of a clear MDS response in C. citrinus may be related to its hydraulic architecture, as Moriana et al. (2003) found in olive trees.

The regression analysis of these indices and the daily plant ET confirmed that there is a relationship between plant water status and dendrometric indices, as has been also reported in several studies (Ortuño et al., 2010). However, in our experiment, when daily plant ET rates were low (in winter), the correlations were weak or not significant $\left(R^{2} \leq 50\right)$. The regression analyses in drought to death showed SGR response to low daily plant ET and $\Psi_{\text {leaf }}$ values, which confirmed the usefulness of this index to provide information on plant water status as reported by Moriana and Fereres (2002) in olive trees. However, in $R$. alaternus and P. tobira, the MDS fit was only useful with daily plant ET and in $R$. alaternus with $\Psi_{\text {leaf }}$. Furthermore, MDS use is more suited to humid soils (Huguet et al., 1992; Ortuño et al., 2004) compared with SGR, which in this study, responded to lower daily plant ET and $\Psi_{\text {leaf }}$ values than MDS (Fig. 6).

The irrigation period fits showed that when there was no water restriction, the transpiration was greater in days with higher water demand (Nicolás, 2003). The dendrometric indices were directly related to the daily plant ET rate, except MNDS and MXDS in winter for $C$. citrinus and $P$. tobira, which may be related to no diameter growth in which just higher water demand reduces the diameter because of water uptake from the stem tissues. Downes et al. (1999) described this behavior as different interactions of cambium activities and environmental conditions in two species of Eucaliptus.

The results described for the different periods of drought reflected different responses that depended on the environmental conditions and the species. For example, in winter, MNDS needed more days to decrease significantly than in spring and summer. However, even thought the indices responded more quickly in severe environmental conditions, the $\Psi_{\text {leaf }}$ response was usually faster ( 1 or $2 \mathrm{~d}$ after the drought started). Under drought to death conditions, the $\Psi_{\text {leaf }}$ was more sensitive than the dendrometric indices, as reported in the results section (SGR or MDS did not respond until $\Psi_{\text {leaf }}$ less than $-3.00 \mathrm{MPa}$ ). This was contrary to the findings of other authors (e.g., Ortuño et al., 2010). This different behavior could be related to the speed at which water is used; this may activate a regulation mechanism that increases the stomatal resistance when the water reserves of the cultivation media are decreasing and affect the $\Psi_{\text {leaf }}($ Bañón et al., 2003). Moreover, the use of pots implies that the substrate water is used in a more uniform way compared with soil, in which variability increases as the stress becomes more pronounced (Russo et al., 1994).

In conclusion, dendrometric indices are sensitive to water stress in small ornamental shrubs. MXDS and MNDS showed a good response in the studied species, especially under severe environmental conditions, although $\Psi_{\text {leaf }}$ was more sensitive to water stress. The SGR and the MDS in the drought to death period were sensitive to daily plant ET ratios between 130 and $300 \mathrm{~mL} \cdot \mathrm{d}^{-1}$, respectively, and to $\Psi_{\text {leaf }}$ less than $-3.00 \mathrm{MPa}$. C. citrinus showed no correlations with MDS- $-\Psi_{\text {leaf }}$, and $\Psi_{\text {leaf }}$ could not be determined in P. tobira; on the other hand, $P$. tobira had the best $R^{2}$ for the MDS and SGRdaily plant ET correlations. The correlations obtained for the irrigation periods confirmed the different behaviors of the dendrometric indices under water stress. These results suggest that irrigation could be based on the evolution of these indices, especially SGR in $C$. citrinus, MDS in P. tobira, and both in $R$. alaternus, although a moderate stress may result. This condition may not be a problem for ornamental shrubs, because although it may affect plant growth and quality, it can also be useful for plant hardening and growth control (Bañón et al., 2003). Many different irrigation protocols involving moderate stress have been studied in fruit trees; for example, Ortuño et al. (2009) applied the protocol proposed by Goldhamer and Fereres (2004) to adult lemon trees. The application of this protocol to fruit trees may lead to a loss of production because it submits the trees to a constant deficit between irrigations, which makes application of this criterion more interesting for use in ornamental crops than in fruit trees. However, before irrigation scheduling based on SGR or MDS can be developed for ornamental shrubs, it will be necessary to compare well-irrigated plants with stressed plants and to ensure that the minimum irrigation frequency is at least every other day.

\section{Literature Cited}

Alarcón, J.J., R. Domingo, S. Green, M.J. SánchezBlanco, P. Rodríguez, and A. Torrecillas. 2000. Sap flow as an indicator of transpiration and the water status of young apricot trees. Plant Soil 227:77-85.

Argo, W.R. and J.A. Biernbaum. 1994. Irrigation requirements, root-medium $\mathrm{pH}$, and nutrient concentrations of Easter lilies grown in five peat-based media with and without an evaporation barrier. J. Amer. Soc. Hort. Sci. 119: 1151-1156.

Bañón, S., J. Ochoa, J.A. Franco, M.J. SánchezBlanco, and J.J. Alarcón. 2003. Influence of water deficit and low air humidity in the nursery on survival of Rhamnus alaternus seedlings following planting. J. Hort. Sci. Biotechnol. 78:518-522.

Burnett, S.E. and M.W. van Iersel. 2008. Morphology and irrigation efficiency of Gaura lindheimeri grown with capacitance sensor-controlled irrigation. HortScience 43:1555-1560. 
Cohen, M., T. Ameglio, P. Cruiziat, P. Archer, C. Valancogne, and L. Ferré. 1993. Las relaciones hídricas en el nogal: Consumo de agua e indicadores de estrés hídrico. I Simposio Hispano-Portugués de Relaciones hídricas en las Plantas. Palma de Mallorca. p. 93-96.

Cohen, M., D. Goldhamer, E. Fereres, J. Girona, and M. Mata. 2001. Assessment of peach trees responses to irrigation water deficits by continuous monitoring of trunk diameter changes. J. Hort. Sci. Biotechnol. 76:55-60.

De Herralde, F., C. Biel, R. Savé, M.A. Morales, A. Torrecillas, J.J. Alarcón, and M.J. SánchezBlanco. 1998. Effect of water and salt stresses on the growth, gas exchange and water relations in Argyranthemum coronopifolium plants. Plant Sci. 139:9-17.

Downes, G., C. Beadle, and D. Worledge. 1999. Daily stem growth patterns in irrigated Eucalyptus globulus and E. nitens in relation to climate. Trees (Berl.) 14:102-111.

Fereres, E. and D. Goldhamer. 2003. Suitability of stem diameter variation and water potential as indicators for irrigation scheduling of almond trees. J. Hort. Sci. Biotechnol. 78:139-144.

Gallardo, M., R.B. Thompson, L.C. Valdez, and M.D. Fernández. 2006. Response of stem diameter variations to water stress in greenhousegrown vegetables crops. J. Hort. Sci. Biotechnol. 81:483-495.

García-Orellana, Y., M.C. Ruíz-Sánchez, J.J. Alarcón, W. Conejero, M.F. Ortuño, E. Nicolás, and A. Torrecillas. 2007. Preliminary assessment of the feasibility of using maximum daily trunk shrinkage for irrigation scheduling in lemon trees. Agr. Water Manage. 89:167-171.

Garnier, E. and A. Berger. 1986. Effect of water stress on stem diameter changes of peach trees growing in the field. J. Appl. Ecol. 23:193-209.

Ginestar, C. and J.R. Castel. 1996. Use of stem dendrometers as indicators of water stress in dripirrigated citrus trees. Acta Hort. 421:209-219.

Goldhamer, D. and E. Fereres. 2001. Irrigation scheduling protocols using continuously recorded trunk diameter measurements. Irrig. Sci. 20:115-125.

Goldhamer, D. and E. Fereres. 2004. Irrigation scheduling of almond trees with trunk diameter sensors. Irrig. Sci. 23:11-19.

Goldhamer, D., E. Fereres, and M. Salinas. 2003. Can almond trees directly dictate their irrigation? Calif. Agr. 57:138-144.

Huguet, J., S. Li, J. Lorendeau, and G. Pelloux. 1992. Specific micromorphometric reactions of fruit trees to water stress and irrigation scheduling automation. J. Hort. Sci. 67:631-640.

Intrigliolo, D.S. and J.R. Castel. 2004. Continuous measurement of plant and soil water status for irrigation scheduling in plum. Irrig. Sci. 23:93102 .
Li, S., J.G. Huguet, and C. Bussi. 1989. Irrigation scheduling in a mature peach orchard using tensiometers and dendrometers. Irrig. Drain. Syst. 3:1-12.

Link, S., M. Thiede, and M. van Bavel. 1998. An improved strain-gauge device for continuous field measurement of stem and fruit diameter. J. Expt. Bot. 49:1583-1587.

Mathers, H.M. 2003. Summary of temperature stress issues in nursery containers and current methods of protection. Hort Technology 13:617624.

Miralles, J., P.A. Nortes, M.J. Sánchez-Blanco, J.J. Martínez-Sánchez, and S. Bañón. 2009. Above-ground and pot-in-pot production systems for Myrtus communis L. Trans. ASABE 52:93-101.

Molz, F.J. and B. Klepper. 1973. On the mechanism of water-stress-induced stem deformation. Agron. J. 65:304-306.

Montero, J.I., A. Antón, P. Muñoz, and P. Lorenzo. 2001. Transpiration from geranium grown under high temperature sand low humidity in green houses. Agr. For. Meteorol. 107:323332.

Moriana, A. and E. Fereres. 2002. Plant indicators for scheduling irrigation of young olive trees. Irrig. Sci. 21:83-90

Moriana, A., F. Orgaz, E. Fereres, and M. Pastor. 2003. Yield responses of a mature olive orchard to water deficits. J. Amer. Soc. Hort. Sci. 128: 425-431.

Munné-Bosch, S., S. Nogués, and L. Alegre. 1999. Diurnal variations of photosynthesis and dew absorption by leaves in two evergreen shrubs growing in Mediterranean field conditions. New Phytol. 144:109-119.

Navarro, A., S. Bañón, E. Olmos, and M.J. SánchezBlanco. 2007. Effects of sodium chloride on water potential components, hydraulic conductivity, gas exchange and leaf ultrastructure of Arbutus unedo plants. Plant Sci. 172:473-480.

Nemali, K.S. and M.W. van Iersel. 2006. An automated system for controlling drought stress and irrigation in potted plants. Sci. Hort. 110: 292-297.

Nicolás, E. 2003. Utilización de las medidas de flujo de savia para el estudio de las relaciones hídricas del albaricoquero (Prunus armeniaca L.). Thesis doctoral, Universidad Politécnica de Cartagena: 262.

Nortes, P.A., A. Pérez-Pastor, G. Egea, W. Conejero, and R. Domingo. 2005. Comparison of changes in stem diameter and water potential values for detecting water stress in young almond trees. Agr. Water Manage. 77:296-307.

Ortuño, M.F., J.J. Alarcón, E. Nicolás, and A. Torrecillas. 2004. Interpreting trunk diameter changes in young lemon trees under deficit irrigation. Plant Sci. 227:275-280.
Ortuño, M.F., W. Conejero, F. Moreno, A. Moriana, D.S. Intrigliolo, C. Biel, C.D. Mellisho, A. Pérez-Pastor, R. Domingo, M.C. Ruíz-Sánchez, J. Casadesus, J. Bonany, and A. Torrecillas. 2010. Could trunk diameter sensors be used in woody crops for irrigation scheduling? A review of current knowledge and future perspectives. Agr. Water Manage. 97:1-11.

Ortuño, M.F., Y. García-Orellana, W. Conejero, F. Pérez-Sarmiento, and A. Torrecillas. 2009. Assessment of maximum daily trunk shrinkage signal intensity threshold values for deficit irrigation in lemon trees. Agr. Water Manage. 96:80-86.

Ortuño, M.F., Y. García-Orellana, W. Conejero, M.C. Ruíz-Sánchez, J.J. Alarcón, and A. Torrecillas. 2006. Stem and leaf water potentials, gas exchange, sap flow, and trunk diameter fluctuations for detecting water stress in lemon trees. Trees (Berl.) 20:1-8.

Remorini, D. and R. Massai. 2003. Comparison of water status indicators for young peach trees. Irrig. Sci. 22:39-46.

Ritchie, G.A. and T.M. Hinckley. 1975. The pressure chamber as an instrument for ecological research. Adv. Ecol. Res 9:165-254.

Russo, D., J. Zaidel, and A. Laufer. 1994. Stochastic analysis of solute transport in partially saturated heterogeneous soil. 1. Numerical experiments. Water Resour. Res. 30:769-779.

Scholander, P., H.T. Hammel, E.D. Bradstreet, and E.A. Hemmingeen. 1965. Sap pressure in vascular plants. Science 148:339-346.

Sivyer, D., J.R. Harris, N. Persaud, and B. Appleton. 1997. Evaluation of a pan evaporation model for estimating post-planting street tree irrigation requirements. J. Arboricult. 23:250 256.

Snyder, R., R.H. Shaw, and K.T. Dawld. 1986. Vapour pressure deficit and other psychrometric properties of air from temperature and relative humidity. Agr. Res. 2:183-192.

Turner, N.C. 1988. Measurement of plant water status by the pressure chamber technique. Irrig. Sci. 9:289-308.

Wei, X., W. Yanhui, Y. Pengtao, L. Hailong, S. Zhongjie, and G. Wei. 2007. Growth in stem diameter of Larix principis-rupprechtii and its response to meteorological factors in the south of Liupan Mountain, China. Acta Ecol. Sin. 27: 432-441.

Wilson, J.R., M.J. Fisher, E.D. Schulze, G.R Dolby, and M.M. Ludlow. 1979. Comparison between pressure-volume and dewpointhygrometry technique for determining the water relations characteristics of grass and legume leaves. Oecologia 41:77-88.

Yatapanage, K.G. and H.B. So. 2001. The relationship between leaf water potential and stem diameter in sorghum. Agron. J. 93:1341-1343. 